\title{
Influence of energy balance on the somatotrophic axis and matrix metalloproteinase expression in the endometrium of the postpartum dairy cow
}

\author{
D Claire Wathes, Zhangrui Cheng, Mark A Fenwick, Richard Fitzpatrick ${ }^{1}$ and Joe Patton ${ }^{2}$ \\ Reproduction Group, Department of Veterinary Basic Sciences, Royal Veterinary College, London, UK, ${ }^{1}$ Animal \\ Production Research Centre, Mellows Campus, Athenry, Co. Galway, Ireland and ${ }^{2}$ Teagasc Moorepark, Dairy \\ Production Research Centre, Fermoy, Co. Cork, Ireland \\ Correspondence should be addressed to D C Wathes; Email: dcwathes@rvc.ac.uk
}

M A Fenwick is now at Division of Surgery, Oncology, Reproductive Biology and Anaesthetics (SORA), Faculty of Medicine, Imperial College London, Institute of Reproductive and Developmental Biology, Hammersmith Hospital, London W12 0NN, UK R Fitzpatrick is now at Boston Scientific Ireland Ltd, Ballybrit Business Park, Co. Galway, Ireland

\begin{abstract}
Postpartum dairy cows enter a period of negative energy balance (NEB) associated with low circulating IGF1, during which the uterus must undergo extensive repair following calving. This study investigated the effects of NEB on expression of IGF family members and related genes in the involuting uterus. Cows were allocated to two treatments using differential feeding and milking regimes to produce mild NEB or severe NEB (SNEB). Uterine endometrial samples collected 2 weeks post partum were analysed by quantitative PCR. The expression of IGF-binding protein 4 (IGFBP4) mRNA increased in the endometrium of SNEB cows, with trends towards increased IGFBP1 and reduced IGFBP6 expression. There were no significant differences between treatments in mRNA expression of IGF1, IGF2 or of any hormone receptor studied, but significant correlations across all cows in the expression levels of groups of receptors suggested common regulatory mechanisms: type 1 IGF receptor (IGF1R), IGF2R and insulin receptor (INSR); GHR with ESR1; and ESR2 with NR3C1. The expression of IGF1R and INSR also positively correlated with the circulating urea concentration. Matrix metalloproteinases (MMPs) are important in tissue remodelling and can affect IGF signalling via interaction with IGFBPs. The expression levels of MMP1, MMP3, MMP9 and MMP13 mRNAs all showed major upregulation in the endometrium of cows in SNEB and all except MMP9 were highly correlated with expression of IGFBP4. Alpha(2)-HS-glycoprotein (AHSG) and PDK4, two genes implicated in insulin resistance, were also highly expressed in SNEB. These results suggest that cows in SNEB experience alterations to the IGF and insulin signalling pathways in the postpartum endometrium. This may affect the rate of tissue repair with a possible negative impact on subsequent fertility.
\end{abstract}

Reproduction (2011) 141 269-281

\section{Introduction}

Most dairy cows mobilise body fat and muscle tissue immediately after calving, as they cannot at this stage meet the energetic demands for milk production entirely from feed intake (Baumann \& Currie 1980). High rates of body condition score (BCS) loss in the early postpartum period are associated with a severe negative energy balance (SNEB) status, alterations in blood metabolite and hormone profiles and reduced fertility (Wathes et al. 2007a, 2007b, Leroy et al. 2008).

After calving, the uterus must undergo extensive remodelling. This involves a major reduction in size, removal of cellular debris and restoration of normal tissue architecture following expulsion of the placenta
(Gier \& Marion 1968, Leslie 1983). Most cows also acquire uterine bacterial contamination at calving. This is normally cleared within $2-3$ weeks, but about $15 \%$ of animals develop a persistent endometritis in the 3-6 week postpartum period (Foldi et al. 2006, Sheldon et al. 2009). Subclinical endometritis is associated with longer intervals to conception (Fourichon et al. 1999, Gilbert et al. 2005).

We and others have shown that SNEB in early postpartum dairy cows is also associated with poor subsequent fertility. For example, multiparous cows with a low nadir in circulating insulin-like growth factor 1 (IGF1) in the first 2 weeks post partum subsequently failed to conceive (Taylor et al. 2004). An increased rate of uterine involution is associated with earlier 
resumption of ovarian activity (Mateus et al. 2002), which is in turn important for increasing the pregnancy rate to first service (Thatcher et al. 2006). Fertility is strongly linked to the animal's health around calving and both retained fetal membranes and excessive lipid mobilisation are associated with reproductive disorders (Lewis 1997). The risk of uterine disease increases in cows with a high liver fat content, with differences becoming apparent around 7-10 days post partum (Zerbe et al. 2000). It is thus likely that a poor environment within the reproductive tract is a contributing factor to subsequent poor conception rates.

The postpartum uterus is exposed to the prevailing metabolic environment within the animal, including reduced concentrations of glucose and IGF1 and raised concentrations of non-esterified fatty acids (NEFAs) and $\beta$-hydroxybutyrate (BHB; Baumann \& Currie 1980, Wathes et al. 2007a, 2007 b). In addition, many members of the somatotrophic axis are expressed locally within the endometrium (Rutanen 1998, Wathes et al. 1998). IGF1 and IGF2 can influence proliferation, differentiation and metabolic activities, principally acting through the type 1 IGF receptor (IGF1R). Further control is achieved via competitive binding to the IGF-binding proteins (IGFBPs), whose expression is regulated in a tissue-specific manner and is also influenced by metabolic status (Thissen et al. 1994, Clemmons 1997). We have shown previously that IGF1, IGF2 and IGF1R are expressed in the postpartum uterus and may therefore play a role in uterine involution (Llewellyn et al. 2008).

Insulin concentrations also tend to be lower in postpartum cows (Bell 1995, Wathes et al. 2007 C). However, the main control of the insulin signalling pathway occurs downstream of the insulin receptor (INSR); impaired signalling is associated with insulin resistance in peripheral tissues (White 2006). Activation of the INSR results in tyrosine phosphorylation of IRS proteins -1 and -2 . Phosphorylated IRSs then bind to proteins such as the p85 regulatory subunit of phospatidylinositol 3-kinase, which has a central role in mediating the metabolic actions of insulin, including glucose uptake (Shepherd 2005, White 2006). Pyruvate dehydrogenase kinase 4 (PD4K) is a mitochondrial protein, which also contributes to the regulation of glucose metabolism by promoting the use of long-chain fatty acids (LCFA) over glucose as an energy substrate when the glucose supply is limited (Holness \& Sugden 2003). Alpha(2)-HS-glycoprotein (AHSG) is a plasma protein, produced primarily by the liver, whose circulating concentration is positively associated with insulin resistance and liver fat accumulation in humans (Stefan et al. 2006). Circulating AHSG rises during late pregnancy, particularly in women with gestational diabetes (Kalabay et al. 2002).

Matrix metalloproteinases (MMPs) are primarily known for their ability to degrade extracellular matrix, but they can also degrade non-matrix proteins (Nagase et al. 2006). In relation to the uterus, they have been studied most extensively in humans, where increased MMP expression is associated with endometrial breakdown during menstruation (Salamonsen et al. 2002).

In this study, we have used a model of differential feeding and milking regimes to produce cows in differing energy balance (EB) status in early lactation (mild NEB (MNEB) or SNEB) as confirmed by markedly divergent metabolic and endocrine profiles. We have previously reported differential expression of the IGF system in both liver and oviduct between the two groups of cows (Fenwick et al. 2008a, 2008b). This study extends these findings by examining the expression patterns for members of the somatotrophic axis and associated pathways in the postpartum endometrium. The objective of this study is to test our hypothesis that altered insulin and IGF1 signalling at this critical time may delay uterine repair mechanisms, thus compromising fertility. Uterine tissue samples were collected during the period of postpartum anoestrus before any cows had ovulated, thus avoiding potential differences between animals associated with exposure to luteal progesterone. The study focused on i) the members of the somatotrophic axis (IGF1, IGF2, IGFBP1-6 and the acid labile subunit (IGFALS); ii) the associated hormone receptors (IGF1R, $I G F 2 R, I N S R, G H$ receptor $(G H R)$ and oestradiol receptors (ESR1 and ESR2)); and iii) the glucocorticoid receptor (Bos taurus nuclear receptor subfamily 3, group C, member 1, transcript variant 4, NR3C1). Some additional candidate genes were selected for analysis based on significant differential expression in a microarray analysis of endometrial samples from the same cows (Wathes et al. 2009) together with their known involvement in either glucose metabolism or the IGF system. These were i) the matix metalloproteinases MMP1, MMP3, MMP9 and MMP13 and ii) PDK4 and AHSG. Gene expression was also related to a variety of endocrine and metabolic measurements made at the time of sample collection.

\section{Results}

\section{Metabolic, hormonal and EB status of cows in MNEB and SNEB}

The $E B$ values and metabolic data from cows at the time of sample collection are summarised in Fig. 1A-E. As reported previously (Fenwick et al. 2008a), all cows were in a state of NEB from the beginning of the treatment period to slaughter at $14 \pm 0.4$ days post partum. The SNEB cows experienced a greater reduction in EB values throughout the early postpartum interval leading to a significantly lower mean $E B$ value at the time of tissue collection. Systemic NEFA and BHB values were elevated, while glucose was reduced and urea concentration remained unchanged in SNEB when compared with the MNEB group. Mean plasma IGF1 concentrations were not different between the groups 

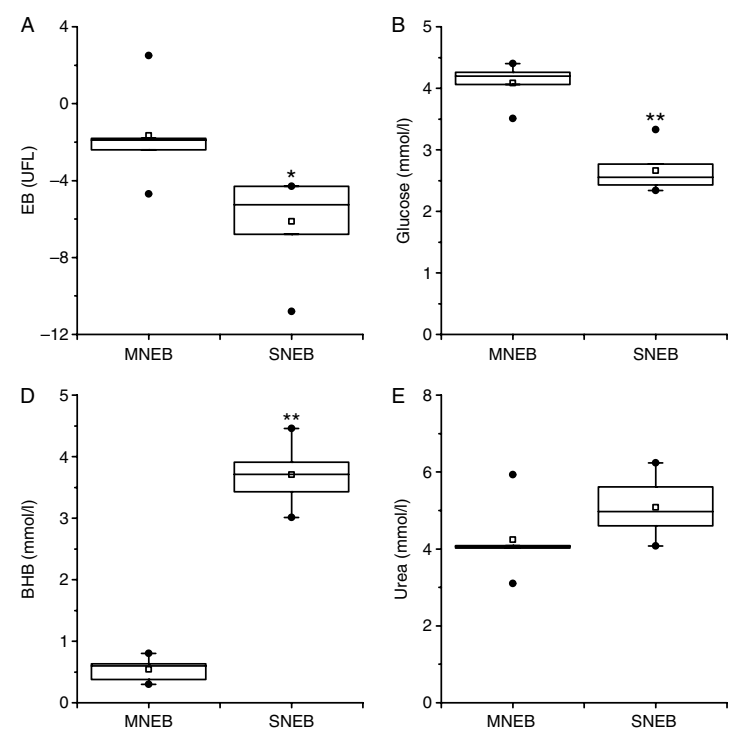
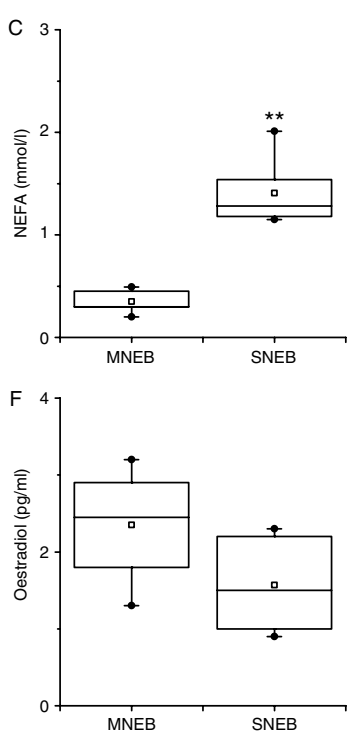

Figure $1 \mathrm{Box}$ and whisker plots to show the $\mathrm{EB}$ values $(A)$, metabolic status (B-E, glucose, NEFA, $\mathrm{BHB}$ and urea) and oestradiol concentrations (F) in blood samples collected pre-slaughter at $14 \pm 0.4$ days post partum. Data are from five cows in MNEB and six in SNEB. The boxes illustrate the median values and the upper and lower quartiles for each group. The mean (open square) and the 99 and 1 percentile values (filled circle) are also shown. There are significant differences between the groups for $\mathrm{EB}$, glucose, NEFA and BHB: ${ }^{*} P<0.05,{ }^{* *} P<0.01$. These results have been reported previously (Llewellyn et al. 2007, Fenwick et al. 2008a, 2008b). during the first week of lactation but during the second week IGF1 remained depressed in SNEB cows, whereas concentrations started to increase in MNEB cows: circulating values therefore differed significantly at the time of slaughter (Fig. 2A). Insulin values tended to increase after calving in the MNEB group but decreased in the SNEB group, although the differences were not significant (Fig. 2B). We report here for the first time the circulating values of cortisol and $\mathrm{GH}$ : these were both quite variable and did not differ significantly between the groups (Fig. 2C and D). The concentrations of oestradiol were also similar between the two treatment groups (Fig. 1F; Llewellyn et al. 2007).
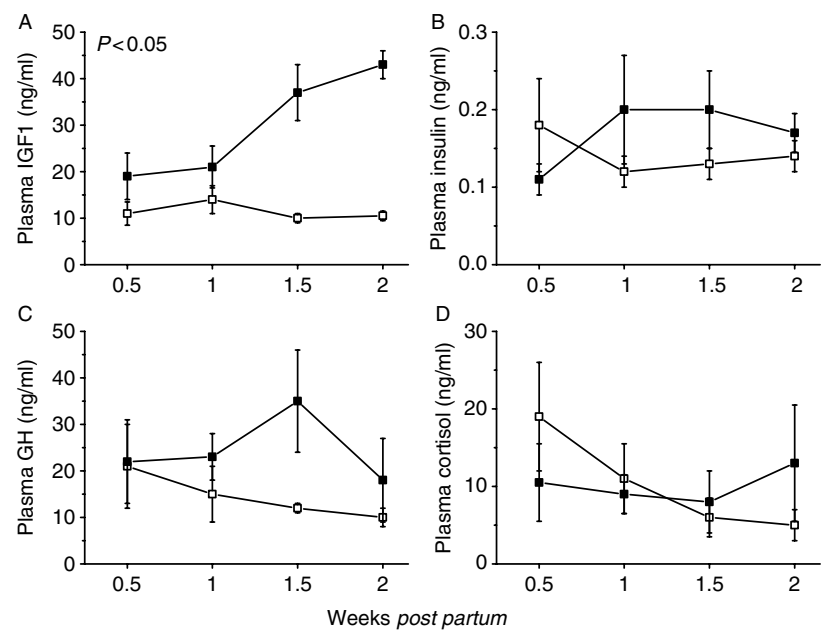

Figure 2 Circulating values of (A) IGF1, (B) insulin, (C) GH and (D) cortisol during the early postpartum period in dairy cows. Values are least squares means \pm s.E.M for the MNEB (filled square; $n=5$ ) and SNEB (open square; $n=6$ ) groups respectively. Circulating IGF1 concentrations in the 2nd week were significantly higher in the MNEB group but values for insulin, $\mathrm{GH}$ and cortisol were not significantly different between the groups (analysed using a repeated measure ANOVA).

\section{Quantitative gene expression profile in the endometrium}

A comparison of the quantitative real-time PCR (qPCR) data for the 25 genes measured in the endometrium according to the EB status is given in Table 1. All IGF family members measured were detectable, but the only gene to show significant differential expression between the groups was IGFBP4, which was 2.6-fold higher in the SNEB group $(P<0.05)$. There were, however, trends for IGFBP1 (higher in SNEB, $P<0.06$ ), IGFBP6 (lower in SNEB, $P<0.08$ ) and IGFALS (lower in SNEB, $P<0.1$ ). The expression of both IGF1 and IGF2 mRNAs was numerically higher in MNEB cows, but the differences were not significant. None of the receptors measured (IGF1R, IGF2R, INSR, GHR, NR3C1, ESR1 or ESR2) differed with the EB status $(P=0.26-0.94)$.

In contrast, there were major differences in expression for all of the MMPs measured: MMP1, MMP3, MMP9 and MMP13 mRNAs showed major upregulation in SNEB cows $(P<0.001)$. AHSG mRNA expression was also much higher in SNEB endometrium $(P<0.001)$. $P D K 4$ was highly expressed and tended to be increased in the endometrium of SNEB cows $(P=0.1)$. The control housekeeping genes (RLP19, GAPDH and 18SrRNA) all showed similar levels of expression in the endometrium between the two groups, confirming that equivalent concentrations of input RNA were used.

\section{Correlation analysis}

Correlation analysis was next performed to identify any relationships between the expression patterns of the genes examined. For this purpose, data were combined between both groups of cows. In addition, an analysis of covariance was performed between the pairs of 
Table 1 Comparison of results for qPCR measurements (expressed in $\mathrm{fg} / \mu \mathrm{g}$ reverse-transcribed RNA) in the endometrium between postpartum cows in mild (MNEB) or severe negative energy balance (SNEB) after calving.

\begin{tabular}{lccc}
\hline Gene & MNEB $\left(n=5^{\mathrm{a}}\right)$ & SNEB $(n=6)$ & $\boldsymbol{P}^{*}$ \\
\hline IGF family members & & & \\
IGF1 & $16 \pm 4.3$ & $8 \pm 3.2$ & 0.19 \\
IGF2 & $7.8 \pm 2.03$ & $4.8 \pm 1.21$ & 0.22 \\
IGFBP1 & $0.5 \pm 0.16$ & $2.1 \pm 0.76$ & 0.06 \\
IGFBP2 & $1.2 \pm 0.10$ & $0.9 \pm 0.26$ & 0.26 \\
IGFBP3 & $6.8 \pm 1.46$ & $9.2 \pm 1.65$ & 0.31 \\
IGFBP4 & $3.5 \pm 0.77$ & $9.2 \pm 3.00$ & 0.05 \\
IGFBP5 & $4.5 \pm 0.78$ & $6.1 \pm 1.57$ & 0.40 \\
IGFBP6 & $5.8 \pm 1.12$ & $3.0 \pm 0.89$ & 0.08 \\
IGFALS & $0.2 \pm 0.03$ & $0.1 \pm 0.05$ & 0.10 \\
Hormone receptors & & & \\
IGF1R & $0.7 \pm 0.10$ & $1.1 \pm 0.32$ & 0.35 \\
IGF2R & $0.2 \pm 0.04$ & $0.4 \pm 0.14$ & 0.26 \\
INSR & $0.6 \pm 0.12$ & $0.9 \pm 0.18$ & 0.28 \\
GHR & $6.8 \pm 1.15$ & $5.2 \pm 1.47$ & 0.42 \\
NR3C1 & $0.9 \pm 0.28$ & $0.8 \pm 0.22$ & 0.91 \\
ESR1 & $24 \pm 5.1$ & $26 \pm 2.9$ & 0.94 \\
ESR2 & $2.1 \pm 0.83$ & $1.3 \pm 0.51$ & 0.42 \\
Tissue remodelling & & & \\
MMP1 & $0.2 \pm 0.10$ & $11.1 \pm 6.09$ & $<0.01^{\#}$ \\
MMP3 & $0.1 \pm 0.04$ & $1.9 \pm 0.97$ & $<0.01^{\#}$ \\
MMP9 & $0.3 \pm 0.11$ & $2.0 \pm 0.55$ & 0.02 \\
MMP13 & $0.1 \pm 0.03$ & $0.5 \pm 0.25$ & $0.03^{\#}$ \\
Insulin signalling & & & \\
AHSG & & & \\
PDK4 & $0.1 \pm 0.02$ & $1.2 \pm 0.52$ & $<0.01$ \\
Housekeeping genes & $29 \pm 10.0$ & $53 \pm 8.6$ & 0.10 \\
RPL19 & & & \\
GAPDH & $28 \pm 2.3$ & $24 \pm 4.5$ & 0.81 \\
18SrRNA & $19 \pm 2.6$ & $27 \pm 7.1$ & 0.36 \\
\hline
\end{tabular}

*Values are presented as mean \pm s.E.M. Comparison between the groups was by $t$-test, those indicated by ${ }^{\#}$ used log-transformed data to normalise variances.

${ }^{a}$ Only five cows were included in the MNEB group due to poor RNA quality for one cow.

variables with the treatment (MNEB or SNEB) included as a fixed effect.

This approach revealed three major groupings of genes whose expressions in the endometrium were significantly inter-related (Table 2). The first group included most of those genes for which a main effect of EB treatment had already been detected: MMP1, MMP3, MMP13, AHSG, IGFBP4, IGFBP1 and PDK4. These correlations remained significant, however, even when the EB status was accounted for in the model. Examples are illustrated in Fig. 3A-D. The group also included the IGF2R; although this was not differentially expressed according to the EB group it did show a positive correlation with the expression levels of MMP3, MMP13, IGFBP4 and PDK4 (Fig. 3E). The expression levels of several of these genes (MMP1, MMP3, MMP13, IGFBP4, AHSG, PDK4) also showed a significant positive correlation with the circulating concentration of NEFA at the time of slaughter (Fig. 3F), but not with the other metabolites measured.

The second major group of inter-related genes included INSR, IGF1R, IGF2R, IGFBP3, IGFBP5 and
PDK4. Examples are illustrated in Fig. 4A-E. Of these, only $P D K 4$ showed a trend for differential expression between the EB groups. The expression of INSR, IGF1R, IGFBP3 and IGFBP5 was positively correlated with the circulating urea concentration, although this relationship did not remain significant when the false discovery rate was accounted for (Fig. 4F).

The third group of genes included IGF1, GHR, ESR1, IGFBP2, IGFBP6 and IGF2. The expression of these genes did not show any correlation with the metabolites or metabolic hormones measured, although there was a trend towards an EB treatment effect for IGFBP6. There were highly significant correlations of IGF1 mRNA expression with GHR, ESR1, IGFBP2 and IGFBP6, whereas IGF2 mRNA expression was only weakly related to IGFBP2 and IGFBP6. Examples are shown in Fig. 5A-D.

Two other sets of genes showed highly significant correlations with each other but not with any of the other genes measured. The two receptors $N R 3 C 1$ and ESR2 were significantly positively related with each other ( $r=0.816, P<0.01$, Fig. 5E) and MMP9 expression was negatively correlated with IGFALS $(r=-0.897$, $P<0.001$, Fig. 5F).

\section{Discussion}

This study describes the results from the model that we have developed in which differential feeding and milking regimes were used to produce cows in differing EB status in early lactation (Fenwick et al. 2008a, 2008b). Within the members of the somatotrophic axis measured, only IGFBP4 mRNA expression varied according to the EB status, although there were trends for IGFBP1, IGFBP6 and IGFALS mRNAs. It is possible that these differences would have achieved a greater level of significance if more animals had been available for the study. However, several MMPs and also AHSG expression were highly upregulated in SNEB, and the products of these genes are known to play a key role in controlling the localisation and breakdown of IGFBP protein within tissues.

Uterine involution in dairy cows involves a considerable reduction in size, necrosis of the surface endometrium and extensive restructuring of the extracellular matrix (Gier \& Marion 1968, Leslie 1983). Placental tissues remaining in the uterus after calving accumulate as tissue debris in the uterine lumen contributing to a lochial discharge. Following this initial degradation, tissue repair is initiated and the caruncles remodel and regenerate epithelium. Many processes involved in uterine repair post partum are thus common to those of wound healing in other tissues, where IGF1 and IGF2 are known to assist the repair mechanisms (GrazulBilska et al. 2003, Salamonsen 2003). In cows, this process is superficially completed by 3-4 weeks post partum, but the deeper layers are not fully restored until 6-8 weeks (Marion \& Gier 1959). 
Table 2 Summary of significant Pearson correlations across all 11 cows in the study for relationships between qPCR gene expression values measured in the endometrium or between gene expression and pre-slaughter circulating non-esterified fatty acid (NEFA) and urea concentrations ${ }^{\mathrm{a}}$.

\begin{tabular}{|c|c|c|c|c|c|c|c|c|}
\hline Group 1 & MMP3 & MMP13 & AHSG & IGFBP4 & IGFBP1 & IGF2R & PDK4 & NEFA \\
\hline MMP1 & $0.979^{\ddagger}(<0.001)$ & $0.961^{\ddagger}(<0.001)$ & $0.924^{\ddagger}(<0.001)$ & $0.931^{\ddagger}(<0.001)$ & $0.702(0.016)$ & NS & $0.600(0.051)$ & $0.693 *(0.018)$ \\
\hline MMP3 & & $\mathbf{0 . 9 8 2}^{\ddagger}(<\mathbf{0 . 0 0 1})$ & $\mathbf{0 . 8 9 2}^{\ddagger}(<\mathbf{0 . 0 0 1})$ & $\mathbf{0 . 9 4 6}^{\ddagger}(<\mathbf{0 . 0 0 1})$ & NS & $0.675(0.023)$ & $0.611(0.046)$ & $0.690 *(0.019)$ \\
\hline MMP13 & & & $\mathbf{0 . 8 8 6}^{\dagger}(<\mathbf{0 . 0 0 1})$ & $0_{0.918^{\ddagger}}(<0.001)$ & $0.675(0.046)$ & $0.738 *(0.009)$ & $0.675(0.023)$ & $0.716 *(0.013)$ \\
\hline$A H S G$ & & & & $0.726^{*}(0.006)$ & $0.825(0.006)$ & NS & NS & $0.682(0.021)$ \\
\hline IGFBP4 & & & & & NS & $0.679(0.022)$ & $0.728(0.011)$ & $0.695 *(0.018)$ \\
\hline IGFBP1 & & & & & & NS & $0.697(0.017)$ & \\
\hline IGF2R & & & & & & & $0.735(0.01)$ & NS \\
\hline$P D K 4$ & & & & & & & & $0.643(0.033)$ \\
\hline Group 2 & IGF1R & IGF2R & IGFBP3 & IGFBP5 & PDK4 & Urea & & \\
\hline INSR & $0.903^{\ddagger}(<0.001)$ & $0.812^{\dagger}(0.002)$ & $0.857^{+}(0.001)$ & $0.754 *(0.007)$ & NS & $0.615(0.044)$ & & \\
\hline IGF1R & & $0.901^{\ddagger}(<0.001)$ & $\mathbf{0 . 8 7 9}^{\ddagger}(<\mathbf{0 . 0 0 1})$ & $0^{-828^{\dagger}}(0.002)$ & $0.679(0.022)$ & $0.643(0.033)$ & & \\
\hline IGF2R & & & $0.789^{+}(0.004)$ & $0.891^{\ddagger}(<0.001)$ & $0.735 *(0.01)$ & NS & & \\
\hline IGFBP3 & & & & $0.683(0.021)$ & $0.814^{+}(0.002)$ & $0.631(0.037)$ & & \\
\hline IGFBP5 & & & & & $0.643(0.033)$ & $0.629(0.038)$ & & \\
\hline PDK4 & & & & & & NS & & \\
\hline Group 3 & GHR & ESR1 & IGFBP2 & IGFBPG & IGF2 & & & \\
\hline IGF1 & $0.892^{\ddagger}(<0.001)$ & $0.753^{\dagger}(0.007)$ & $0.731 *(0.011)$ & $0819^{+}(0.002)$ & NS & & & \\
\hline GHR & & $0.797^{\dagger}(0.003)$ & $0.839^{\dagger}(0.001)$ & $0.802^{+}(0.003)$ & NS & & & \\
\hline ESR1 & & & NS & NS & NS & & & \\
\hline IGFBP2 & & & & $0.776^{*}(0.005)$ & $0.634(0.036)$ & & & \\
\hline IGFBP6 & & & & & $0.669(0.024)$ & & & \\
\hline
\end{tabular}

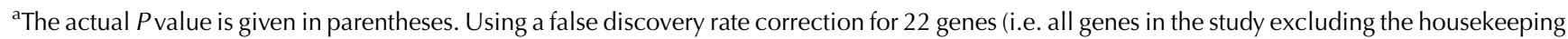
genes), adjusted $5 \%$ significance is at $P=0.026$ and adjusted $1 \%$ significance is at $P=0.005$, shown in bold. NS, not significant. The data were also tested using analysis of covariance between the pairs of variables with the treatment (MNEB or SNEB) included as a fixed effect. The significance level for this test is indicated: $* P<0.05,{ }^{\dagger} P<0.01$ and ${ }^{\ddagger} P<0.001$.

Both our own work and that of others have demonstrated that many members of the IGF system are expressed in cyclic and postpartum bovine uterus (Geisert et al. 1991, Robinson et al. 2000, Pershing et al. 2002, Llewellyn et al. 2008). Within the postpartum cow, in situ hybridisation analysis showed that IGF1 mRNA was present in the subepithelial stroma, whereas IGF2 mRNA was confined to the caruncular stroma. IGFBP2, IGFBP4, IGFBP5 and IGFBP6 mRNAs all showed widespread distribution in both the intercaruncular and caruncular stroma in contrast with IGFBP3 mRNA, which was strongly expressed in the luminal epithelium only (Llewellyn et al. 2008). We were unable to detect IGFBP1 mRNA expression using our in situ hybridisation technique (Llewellyn 2008), although it was measurable in this study by qPCR.

The qPCR analysis showed that expression of IGFBP4 mRNA was higher in the endometrium of cows in SNEB and there were trends towards an increased expression in IGFBP1 and a reduction in IGFBP6 and IGFALS mRNAs. The result relating to IGFBP6 was supported by in situ hybridisation analysis, which showed a significant reduction in IGFBP6 mRNA expression in cows in SNEB (Llewellyn 2008). IGFBP6 mRNA expression in the oviduct also decreased in SNEB relative to MNEB (Fenwick et al. 2008b). This limited effect of the EB status on the somatotrophic axis in the uterus contrasted with the major influence on the liver. Hepatic expressions of IGF1, IGF1R, IGF2R, IGFBP3, -4, -5, -6, IGFALS and GHR mRNAs were all significantly downregulated in cows in SNEB, whereas expression of IGFBP2 mRNA increased (Fenwick et al. 2008a). In this study, IGFBP1 mRNA in the endometrium was higher in cows in SNEB, whereas hepatic expression of IGFBP1 reduced. In the oviduct, expression of IGFBP2 mRNA decreased in SNEB relative to MNEB, whereas it increased in the liver (Fenwick et al. 2008b). Together, these results show clearly that there is differential regulation of components of the IGF system in different tissues by EB in the postpartum cow, even though these tissues are all exposed to the same prevailing endocrine background of elevated BHB and NEFA alongside reduced concentrations of IGF1 and glucose.

IGF1 mRNA was highly expressed in the postpartum endometrium. In the liver, the main regulator of IGF1 synthesis is GH coupling to GHR (Lucy et al. 2001). In rats, $\mathrm{GH}$ can also increase the uterine IGF1 expression, although oestradiol seems to be the major regulator of IGF1 expression within the reproductive tract (Murphy \& Friesen 1988). We have previously reported increased expression of IGF1 in subepithelial stroma of both sheep and cows at oestrus, with significant correlations with the expression of ESR1 in the same cells (Stevenson et al. 1994, Robinson et al. 2000). During NEB the GH-IGF 

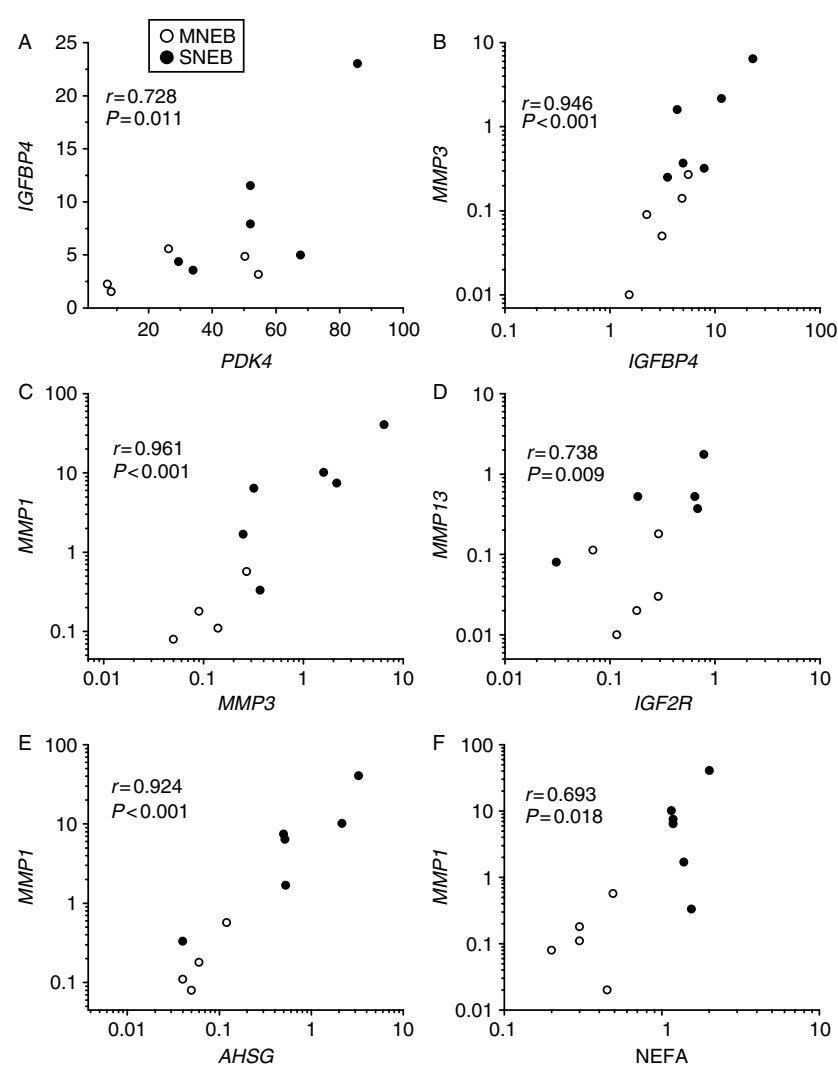

Figure 3 Scatter plots illustrating significant correlations between gene expression levels (in $\mathrm{fg} / \mu \mathrm{g}$ reverse-transcribed RNA; A-E) and NEFA concentrations (in $\mathrm{mmol} / \mathrm{l} ; \mathrm{F}$ ) for all cows in the study $(n=11)$. Examples are taken from Table 2, group 1. Each symbol represents one animal with MNEB cows shown as open symbols and SNEB cows as solid symbols.

axis uncouples due to downregulation in hepatic GHR (Lucy et al. 2001, Fenwick et al. 2008a) and this is the major factor causing reduced IGF1 synthesis in the postpartum cow (Kobayashi et al. 1999). Pershing et al. (2002), however, found no effect of bovine somatotrophin treatment on bovine endometrial IGF1 expression. In the present experiment, mRNA for both $\mathrm{GH}$ and oestradiol receptors was present in the endometrium but there were no differences in circulating $\mathrm{GH}$ or oestradiol or between endometrial GHR, ESR1 or ESR2 mRNA expression between the EB groups. There were, however, highly significant correlations between the expression levels of IGF1, GHR and ESR1 in individual cows. It is therefore likely that both oestradiol and $\mathrm{GH}$ are involved in regulating endometrial IGF1 synthesis in the postpartum cow. There may also be effects of the EB status on downstream signalling from the receptors that were not investigated in this study.

Both IGFBP6 and IGFBP4 mRNAs showed widespread distribution in the endometrial stromal cells from the cows in this study (Llewellyn et al. 2008) and both these IGFBPs were regulated by the EB status although in opposite directions. IGFBP4 is the smallest IGFBP: it binds both IGF1 and IGF2 and is often co-expressed with IGF2 during development (Ning et al. 2008). IGFBP4 production increased during decidualisation of human endometrial stromal cells (Ganeff et al. 2009). Although it is generally thought to inhibit IGF action (Wetterau et al. 1999), recent studies revealed that the null mutation of IGFBP4 in mice led to a prenatal growth deficit, suggesting that it may also provide a reservoir of IGF within tissues (Ning et al. 2008). IGFBP6 has a much higher affinity for IGF2, generally inhibiting IGF2 activity (Bach 1999, Grellier et al. 2002, Bach 2005). Potential regulators of IGFBP6 expression are retinoic acid and oestrogen (Zhu et al. 1993, Bach 1999). The present results also showed a trend towards increased IGFBP1 mRNA expression in the endometrium of cows in SNEB. In humans, IGFBP1 is a major product of the decidual stroma, where its production is decreased by both insulin and IGFs (Rutanen 1998, Giudice 2006), whereas in sheep IGFBP1 expression was mainly present in the luminal epithelium, rising during the second half of the luteal phase (Osgerby et al. 1999). In rat liver, production of IGFBP1 increases during inflammation
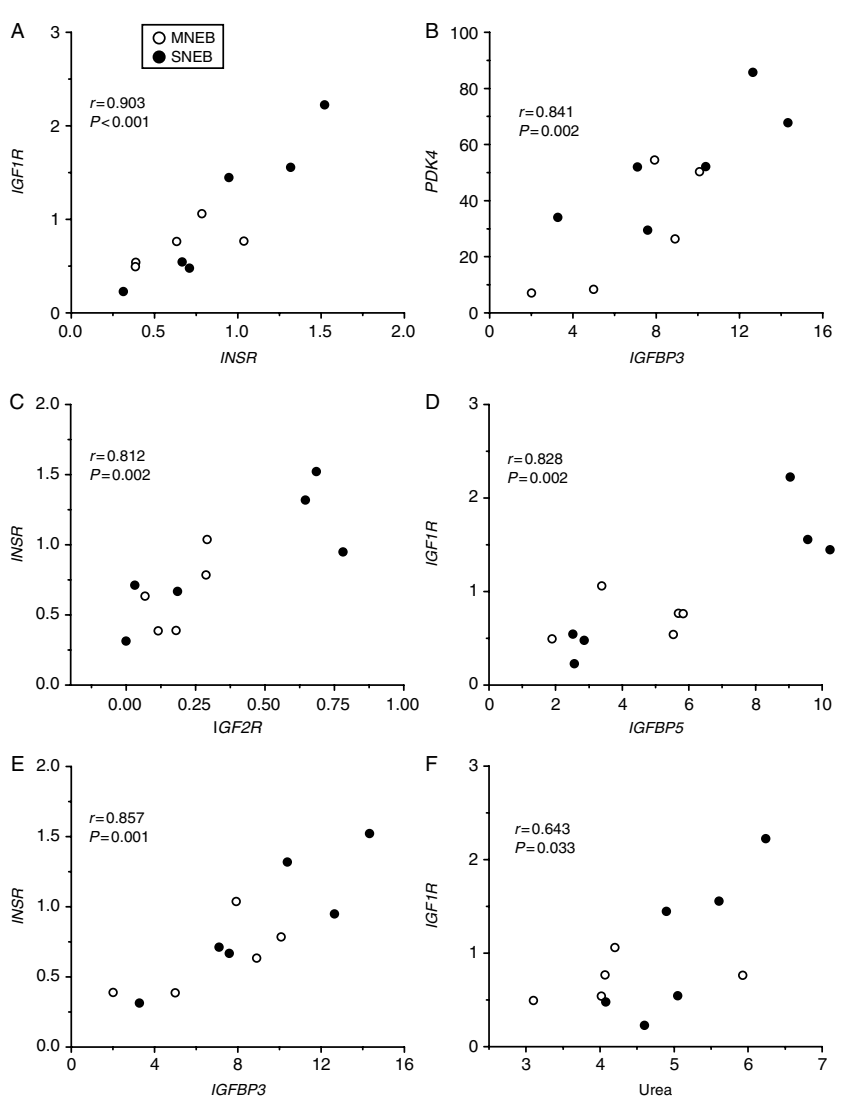

Figure 4 Scatter plots illustrating significant correlations between gene expression levels (in $\mathrm{fg} / \mu \mathrm{g}$ reverse-transcribed RNA; A-E) and urea concentrations (in mmol/l; F) for all cows in the study $(n=11)$. Examples are taken from Table 2, group 2. Each symbol represents one animal with MNEB cows shown as open symbols and SNEB cows as solid symbols. 

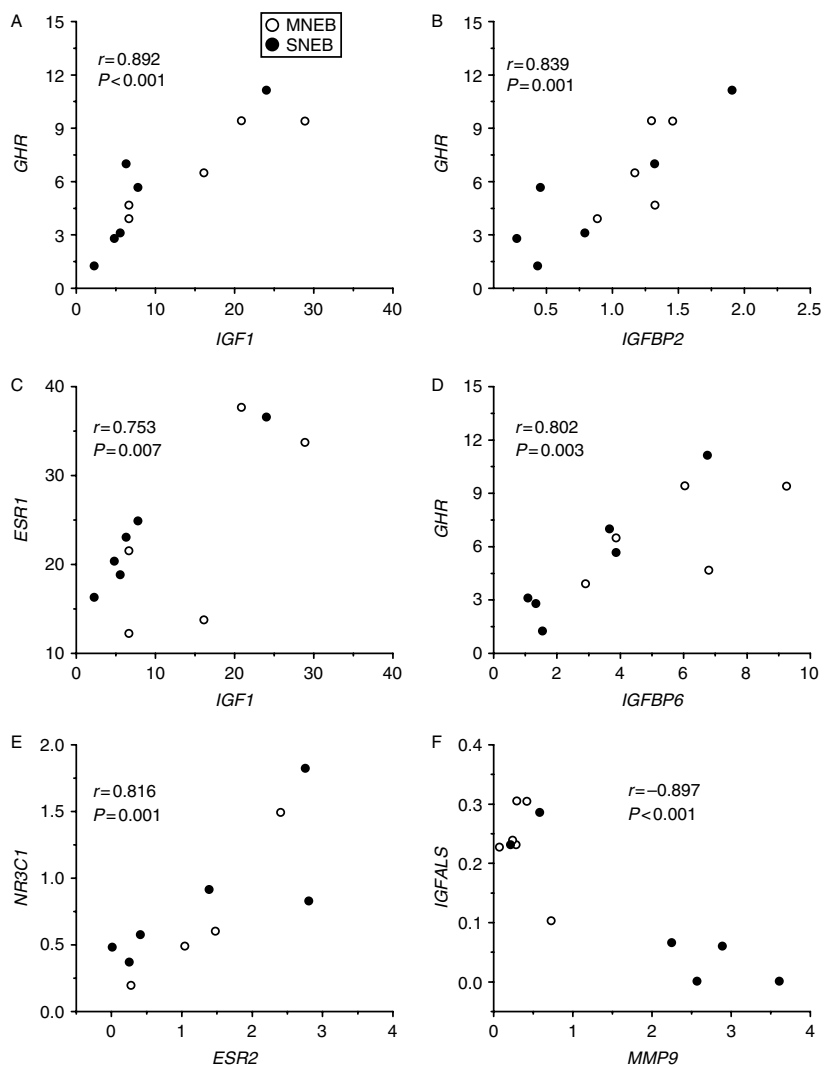

Figure 5 Scatter plots illustrating significant correlations between gene expression levels (in $\mathrm{fg} / \mu \mathrm{g}$ reverse-transcribed RNA) for all cows in the study. Each symbol represents one animal $(n=11)$ with MNEB cows shown as open symbols and SNEB cows as solid symbols. For (A-D) examples are taken from Table 2, group 3.

and expression can be stimulated by IL1B (Rutkute \& Nikolova-Karakashian 2007). The results suggest that the actions of the IGFs in the postpartum uterus will be highly controlled by the various IGFBPs present and that there is differential regulation of some of the IGFBPs according to the energy status. However, both the actions of the IGFBPs and the precise mechanisms controlling their expression in the endometrium remain to be elucidated.

The expression of IGFALS mRNA was also detected in the endometrium, with a trend towards reduced expression in SNEB. IGFALS is a glycoprotein, which forms a ternary complex with IGF and IGFBP3 or IGFBP5, prolonging the half-life of IGF in the circulation. In the liver, the expression is regulated by $\mathrm{GH}$ and we have previously shown a major downregulation of hepatic IGFALS in postpartum cows in concert with decreased expression of IGF1, IGFBP3 and GHR mRNAs (Fenwick et al. 2008a). Although IGFALS is primarily synthesised in the liver, low levels of uterine expression have previously been reported in some extra-hepatic tissues, including the uterus (Lee et al. 2001, Li et al. 2007). In this study, endometrial IGFALS expression showed a strong negative relationship with MMP9, which is generally produced by migratory immune cells (Salamonsen et al. 2002), but the significance of this observation and the function of extra vascular IGFALS are currently unclear. It seems likely that reduced levels of IGFALS would decrease the half-life of locally produced IGFs, although IGF-independent actions are also thought to be possible (Lee et al. 2001).

Another putative regulator of the IGF system within the postpartum uterus is insulin. In late pregnancy, falling insulin and elevated placental lactogen stimulate adipose mobilisation, providing nutrients for fetal growth (Bell 1995, Sivan \& Boden 2003) and resulting in raised circulating concentrations of NEFAs. Lipid accumulation in muscle inhibits tyrosine phosphorylation of IRS (Kirwan et al. 2004) and this contributes to the pregnant mother developing peripheral insulin resistance. In women of normal weight, insulin signalling was restored within a few days of giving birth but this took up to 15 weeks in obese women (Sivan et al. 1997). IGF1 also seems necessary for normal insulin sensitivity (Clemmons 2004). The SNEB cows in this study had significantly higher circulating NEFA and lower IGF1 after calving; therefore, we propose that they may also be subject to impaired peripheral insulin signalling. AHSG is a plasma protein, produced primarily by the liver, whose circulating concentration is positively associated with insulin resistance and hepatic lipidosis in humans (Stefan et al. 2006). Local production of AHSG mRNA within the uterus was 12-fold higher in cows in SNEB and was also positively correlated to the circulating NEFA concentration, so this could potentially contribute to decreased insulin sensitivity.

Energy requirements of cells can be met by either glucose or LCFA. When glucose is scarce and the supply and oxidation of LCFA is sufficient, then mitochondrial pyruvate dehydrogenase activity is suppressed, limiting the conversion of pyruvate to acetyl-CoA and helping to conserve glucose (Holness \& Sugden 2003). PDK activity increases in response to starvation or an increased lipid supply, inactivating the pyruvate dehydrogenase complex. PDK4 is thus thought to act as a marker of lipid status (Holness \& Sugden 2003). It is upregulated across many tissues in type 2 diabetes mellitus, with expression regulated by glucocorticoids, retinoic acid and insulin (Rasche et al. 2008). The increased expression of PDK4 mRNA in the endometrium of cows in SNEB and the correlation of PDK4 expression to the NEFA concentration are therefore consistent with an environment of reduced glucose availability coupled with raised NEFAs.

We also report that the concentrations on endometrial MMP1, MMP3, MMP9 and MMP13 mRNAs were all significantly higher in the SNEB group. Of these, expression levels of MMP1, MMP3 and MMP13 were all highly correlated with each other, but showed no relationship with MMP9 expression. In human uterus, 
MMP1 and MMP3 are both produced by stromal cells and MMP9 by migratory immune cells (reviewed by Salamonsen et al. (2002)). The expression of these MMPs in women increased at menstruation following progesterone withdrawal, when they are thought to be the key players in promoting endometrial breakdown. The increased expression of MMP1, MMP2 and MMP9 was also demonstrated during uterine involution after parturition in the rat (Manase et al. 2006). Different MMPs differ with regard to their substrate specificity: MMP1 and MMP13 act principally as collagenases, whereas MMP3 is a stromelysin, which digests extracellular matrix molecules but not collagen and it is also important for pro-MMP activation (Nagase et al. 2006). The co-ordinated rise in MMP1, MMP3 and MMP13 mRNAs shown in this study suggests that these MMPs share common regulatory mechanisms within the uterus. IL1 and TNF are possible candidates, as both were shown to increase MMP1 and MMP3 protein secretion in human uterine fibroblasts (Braundmeier \& Nowak 2006).

There is also a considerable body of literature linking the MMPs with IGFBP activity. MMPs can cleave IGFBP1, IGFBP3 and IGFBP5, thus, increasing the bioavailability of IGFs for receptor activation by releasing them from association with the extracellular matrix (Nagase et al. 2006). For example, decidualised endometrial cells in first trimester human pregnancy produce both IGFBP1 and MMP3. MMP3 was shown to cleave IGFBP1 into fragments that were unable to bind IGFs, thus, potentially increasing IGF-stimulated placental proliferation (Coppock et al. 2004). MMP expression in this study also highly correlated with that of AHSG. AHSG present on the cell surface can anchor other molecules to the plasma membrane (Ochieng et al. 1995, Leite-Browning et al. 2002). It has been shown to interact with a variety of MMPs (-2, -3, -7 and -9), both activating them and protecting them from autolytic cleavage (Ochieng et al. 1995, Ray et al. 2003, Kübler et al. 2007). Although not studied here, tissue inhibitors of matrix metalloproteinases (TIMPs) are also known to play a key role in regulating MMP activity (Nagase et al. 2006).

A number of hormone receptors were measured (IGF1R, IGF2R, INSR, GHR, NR3C1, ESR1 and ESR2) and in no case did their expression in the endometrium varied according to EB status. Although systemic IGF1 was lower in cows in SNEB, the circulating concentrations of oestradiol, insulin and $\mathrm{GH}$ were similar between the EB groups. This suggests that any effects of EB acting through these receptors must be mediated through alteration of the downstream receptor signalling pathways. The receptors did, however, show coordinated expression between themselves: IGF1R, $I G F 2 R$ and INSR were all highly positively correlated with each other, as were GHR with ESR 1 and NR3C1 with ESR2. The expression of receptors within each of these three groups is therefore likely to be controlled through common use of transcription factors. The IGF2R is thought to degrade IGF2 and so acts to reduce IGF2 signalling (Kornfeld 1992). The co-expression of IGF1R and IGF2R is perhaps surprising given their opposing actions, although similar results were found in hepatic tissues (Fenwick et al. 2008a).

In the cyclic cow, IGF1R is most highly expressed in luminal and glandular epithelial cells, whereas in the postpartum uterus, expression was confined to the stroma (Robinson et al. 2000, Llewellyn et al. 2008). In early pregnancy in the ewe, IGF2R mRNA expression was also mainly localised to the subepithelial stroma (Wathes et al. 1998). Transcription of the IGF1R is mainly under negative control by several transcriptional repressors, but these can be overcome by a number of transactivators, including ESR1 (Werner \& Roberts 2003). Oestrogen is also known to modulate GH action at the level of receptor expression (Leung et al. 2004). In the cyclic and early pregnant cow, ESR 1 in the endometrium is most highly expressed at oestrus; oestradiol is the main upregulator of ESR1, with progesterone having an inhibitory effect (Meyer et al. 1988, Robinson et al. 2001). GHR expression in the endometrium of the non-pregnant cow also peaked at oestrus (Rhoads et al. 2008) but GHR concentrations were higher during pregnancy (Kölle et al. 1997). In mice, ESR2 is more highly expressed in immature than mature uterus with expression negatively regulated by oestradiol. Some evidence suggests a role of ESR2 in controlling collagen homeostasis (reviewed by Koehler et al. (2005)). Glucocorticoid receptors have been identified in the bovine uterus around calving (Schäubli et al. 2008). Further work is clearly needed to unravel how the complex interplay of hormone action on the uterus is regulated between different cell types at a transcriptional level.

One novel finding of this study was that, although expression of the IGFIR and INSR was not altered by the EB status, their expression levels did correlate with the circulating urea concentration, as did expression of IGFBP3 and IGFBP5 mRNA. High circulating urea levels in cows are associated with reduced fertility (reviewed by Laven et al. (2007)), an effect thought to be mediated in part through a reduced $\mathrm{pH}$ in the uterine lumen (Rhoads et al. 2004). Blood urea concentrations after calving are influenced by dietary factors, dry matter intake, ill health (in particular liver disease) and the extent of tissue protein catabolism to meet the demands of lactation (Bell 1995, Grummer 1995, Drackley et al. 2001). The results presented in this study suggest that the resulting urea concentration may influence the expression of endometrial IGF and INSRs. Of potential relevance in this respect is the known inhibitory effect of sulphonylurea drugs in the treatment of non-insulindependent diabetes due to their ability to inhibit insulin signalling pathways (Del Prato et al. 1991). More recently, diarylurea compounds were identified as being potent inhibitors of IGF1R signalling in breast 
cancer cells (Gable et al. 2006), although the correlation detected in this study between urea and receptor expression was positive rather than negative.

When tissues are injured they must undergo the successive repair phases of degeneration, inflammation, regeneration and fibrosis (Prisk \& Huard 2003). In muscle and tendon, local signalling of IGF1 may co-ordinate these responses, allowing better regenerative growth (Dahlgren et al. 2005, Mourkioti \& Rosenthal 2005). IGF1 signalling has also been implicated in tissue remodelling of the human endometrium (Toyofuku et al. 2006). In conclusion, we show in this study that there are alterations in both the IGF bioavailability and in insulin signalling pathways in the endometrium of cows in relation to their EB status in early lactation. Our results reveal a complex network of activity within the postpartum uterus involving MMPs and IGFBPs whose expression is regulated though a combination of inflammatory mediators and metabolic indicators. We suggest that this is likely to affect the ability of the MMPs to promote involution through degradation of the extracellular matrix and will also alter the availability of IGFs to promote proliferation and healing. Delay to the endometrial repair processes when cows are in SNEB may thus be a contributing factor leading to the lower fertility subsequently found in such animals.

\section{Materials and Methods}

All chemicals and reagents were purchased from SigmaAldrich Company Ltd or VWR International Ltd (Poole, Dorset, UK) unless otherwise specified.

\section{Animals and tissue collection}

All procedures were carried out under license in accordance with the European Community Directive, 86-609-EC. From an initial pool of 24 Holstein-Friesian cows with an average previous lactation yield of $6477 \pm 354 \mathrm{~kg}, 12$ multiparous cows were randomly allocated 2 weeks prior to expected calving to either a MNEB $(n=6)$ or SNEB $(n=6)$ treatment, taking account of their parity, BCS and previous lactation yield in a randomised block design. The treatments began in the morning after the second or third milking following parturition. MNEB cows were fed ad libitum grass silage with $8 \mathrm{~kg} /$ day of a $21 \%$ crude protein dairy concentrate and milked once daily; SNEB cows were fed $25 \mathrm{~kg} /$ day silage with $4 \mathrm{~kg} /$ day concentrate and milked three times daily. Similar treatment groupings were shown in a previous study to produce differences in EB in early lactation (Patton et al. 2006).

EB was estimated as the difference between energy intake and the sum of energy for maintenance and milk production, based on measurements of milk yield, milk composition, liveweight and feed intake. The French NE system was used, where 1 unité fourragère lait (UFL) is the net energy for lactation equivalent of $1 \mathrm{~kg}$ standard air-dry barley (Jarrige 1989). Samples of the endometrium were collected from all cows following slaughter at $14 \pm 0.4$ days post partum as described below. This was on days 6-7 of the first follicular wave after calving, before any animal had ovulated, so progesterone levels were still low.

\section{Blood samples and assays}

Blood samples were collected three times weekly from calving (on Mondays, Wednesdays and Fridays) and just prior to slaughter into lithium-heparin primed vials and immediately placed on ice before centrifugation at $2000 \mathrm{~g}$ for $10 \mathrm{~min}$. Plasma was decanted and stored at $-20^{\circ} \mathrm{C}$ for subsequent analysis. Samples of plasma were analysed for glucose, NEFAs, $\beta$-hydroxybutyrates and urea using appropriate kits and an $A B X$ Mira autoanalyser (ABX Mira, Cedex, France). Concentrations of plasma IGF1, insulin and oestradiol were assayed as described and reported previously (Taylor et al. 2004, Llewellyn et al. 2007, Fenwick et al. 2008a).

A double antibody RIA was used for $\mathrm{GH}$ determination where bovine GH (a gift from Dr J Gong, Roslin Institute, Edinburgh, UK) was used for iodination and preparation of the standard curve (Taylor et al. 2004). The antiserum was raised in a guinea pig against bovine $\mathrm{GH}$ and was used at 1:10 000 dilution. The sensitivity of the assay was $1.6 \mathrm{ng} / \mathrm{ml}$. The intraassay coefficient of variation (CV) was $12.9 \%$. Oestradiol concentrations were assayed using the Estradiol MAIA assay kit (BioStat Diagnostic Systems, Stockport, Cheshire, UK).

Cortisol concentrations were measured by RIA. Aliquots of $100 \mu \mathrm{l}$ plasma were extracted with $3 \mathrm{ml}$ diethyl ether in glass tubes, the organic phase was dried down and the sample was reconstituted in $300 \mu \mathrm{l}$ assay buffer. Next, $100 \mu \mathrm{l}$ aliquots of standard or extracted plasma were incubated with first antibody $(100 \mu \mathrm{l}$ sheep anti-bovine cortisol; Diagnostics Scotland, Pennycuick, UK; diluted 1:1000 in assay buffer) and [1, 2, 6, $7{ }^{3} \mathrm{H}$ ]cortisol (Amersham Biosciences Ltd; $100 \mu \mathrm{l}$, $\sim 10000$ c.p.m.) overnight at $4{ }^{\circ} \mathrm{C}$. Separation was by dextran-charcoal. The intra-assay $\mathrm{CV}$ values for samples with a mean of 3.6 and 51.4 cortisol $\mathrm{nmol} / \mathrm{l}$ of plasma were 5.6 and $6.1 \%$ respectively and the sensitivity of the assay was $0.7 \mathrm{nmol} / \mathrm{l}$.

\section{Uterine tissue collection and RNA isolation}

The uterus was opened and samples of intercaruncular endometrial tissue weighing $\sim 1 \mathrm{~g}$ were dissected from the mid portion of the previously gravid horn $\sim 1 \mathrm{~cm}$ anterior to the bifurcation of the uterus. These were rinsed in RNase-free phosphate buffer, snap-frozen in liquid nitrogen and stored at $-80^{\circ} \mathrm{C}$. Total RNA was prepared from 200-300 mg fragmented frozen endometrial tissue and homogenised in TRI reagent (Molecular Research Centre, Inc., Cincinnati, OH, USA). RNA concentration and purity were determined using the NanoDrop ND-1000 spectrophotometer (NanoDrop Technologies, Inc., Wilmington, DE, USA), where all samples had a 260/280 ratio of absorbance between 1.8 and 2.1.

\section{Quantitative real-time PCR}

Optimised qPCR assays were used to detect gene transcripts. A detailed description of these assays has been published 
previously (Fenwick et al. 2008a). Total RNA from each sample was treated for potential genomic DNA carryover in a single reaction in accordance with the guidelines supplied by Promega Corporation. From this reaction, precisely $1 \mu \mathrm{g}$ DNase-treated RNA was reverse transcribed using random hexamer primers and processed accordingly (Reverse Transcription System kit; Promega). A mastermix of reagents was prepared for the above reaction to minimise potential variation. Selected negative control samples were also prepared by including all reagents as above, minus the reverse transcriptase. Gene symbols, sequence information, accession numbers and expected product lengths are provided in Table 3.

Gene transcripts were quantified as described in detail previously (Fenwick et al. 2008a). Standards for qPCR were prepared from purified PCR products that were quantified by spectroscopy (NanoDrop) and diluted over at least eight orders of magnitude. Briefly, for each assay a mastermix was prepared, which contained a final concentration of $1 \times$ absolute qPCR

Table 3 Oligonucleotide primer sequence and expected amplicon size used for real-time PCR assays.

\begin{tabular}{|c|c|c|c|}
\hline Gene & Primer sequence $\left(5^{\prime} \rightarrow 3^{\prime}\right)$ & GenBank accession & Product length $(b p)$ \\
\hline IGF1 & For: AGTTGGTGGATGCTCTCCAGT & NM_001077828.1 & 115 \\
\hline IGF2 & $\begin{array}{l}\text { For: GCTTCTACTTCAGCCGACCAT } \\
\text { Rev: GGCACAGTAAGTCTCCAGCAG }\end{array}$ & NM_174087.3 & 110 \\
\hline IGFBP1 & $\begin{array}{l}\text { For: TCAAGAAGTGGAAGGAGCCCT } \\
\text { Rev: AATCCATTCTTGTTGCAGTTT }\end{array}$ & NM_174554 & 127 \\
\hline IGFBP2 & $\begin{array}{l}\text { For: AGGGTGGCAAACATCACCT } \\
\text { Rev: GAAGGCGCATGGTGGAGAT }\end{array}$ & NM_174555.1 & 120 \\
\hline IGFBP3 & $\begin{array}{l}\text { For: ACAGACACCCAGAACTTCTCCTC } \\
\text { Rev: GTTCAGGAACTTGAGGTGGTTC }\end{array}$ & NM_174556.1 & 102 \\
\hline IGFBP4 & $\begin{array}{l}\text { For: GACCTTTACATCATTCCCATCC } \\
\text { Rev: AAGCTTCACTCCCGTCTTCC }\end{array}$ & NM_174557.3 & 129 \\
\hline IGFBP5 & $\begin{array}{l}\text { For: CAAGCCAAGATCGAAAGAGACT } \\
\text { Rev: AAGATCTTGGGCGAGTAGGTCT }\end{array}$ & NM_001105327.1 & 86 \\
\hline IGFBP6 & $\begin{array}{l}\text { For: GGAGAGAATCCCAAGGAGAGTAA } \\
\text { Rev: GAGTGGTAGAGGTCCCCGAGT }\end{array}$ & NM_001040495.1 & 100 \\
\hline IGFALS & $\begin{array}{l}\text { For: CTTCTGGCTGGACGTCTCC } \\
\text { Rev: AAGGTCCTCAGCGAGTTGTTT }\end{array}$ & NM_001075963.1 & 111 \\
\hline IGF1R & $\begin{array}{l}\text { For: GATCCCGTGTTCTTCTACGTTC } \\
\text { Rev: AAGCCTCCCACTATCAACAGAA }\end{array}$ & XM_606794.3 & 101 \\
\hline IGF2R & $\begin{array}{l}\text { For: TACAACTTCCGGTGGTACACCA } \\
\text { Rev: GGATTTCGCTAGCCTGGAGAG }\end{array}$ & NM_174352.2 & 111 \\
\hline INSR & $\begin{array}{l}\text { For: TCCTCAAGGAGCTGGAGGAGT } \\
\text { Rev: TTTCCTCGAAGGCCTGGGGAT }\end{array}$ & XM_590552.4 & 89 \\
\hline$G H R$ & $\begin{array}{l}\text { For: ACTTGGGCTAGCAGTGACATTA } \\
\text { Rev: TTCCTTTAATCTTTGGAACTGG }\end{array}$ & NM_176608.1 & 101 \\
\hline$N R 3 C 1$ & $\begin{array}{l}\text { For: CTGGGGCCAATATAATTGGTAA } \\
\text { Rev: TTCTGATCCTGCTGTTGAGAAA }\end{array}$ & XM_612999.4 & 124 \\
\hline ESR1 & $\begin{array}{l}\text { For: TCAGGCTACCATTACGGAGTTT } \\
\text { Rev: GTTTTTATCAATCGTGCACTGG }\end{array}$ & NM_001001443.1 & 120 \\
\hline ESR2 & $\begin{array}{l}\text { For: CTTCGTGGAGCTCAGCCTGT } \\
\text { Rev: GAGATATTCTTTGTGTTGGAGTTT }\end{array}$ & NM_174051.3 & 241 \\
\hline MMP1 & $\begin{array}{l}\text { For: GGTCAGGTTTATAGCTTATGGATTC } \\
\text { Rev: TTGAGAGAAGACATCACGGAGA }\end{array}$ & NM_174112.1 & 120 \\
\hline MMP3 & $\begin{array}{l}\text { For: GATGATGAACAATGGACAAAGG } \\
\text { Rev: CGAGGGTCGTAGACTGGGTA }\end{array}$ & XM_586521.2 & 134 \\
\hline MMP9 & $\begin{array}{l}\text { For: GAGGGTAAGGTGCTGCTGTTC } \\
\text { Rev: AAGGTCACGTAGCCCACATAGT }\end{array}$ & NM_174744.2 & 236 \\
\hline MMP13 & 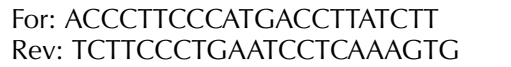 & NM_174389.2 & 162 \\
\hline AHSG & $\begin{array}{l}\text { For: GACTTGCGCCACACTTTCTC } \\
\text { Rev: CTGATTCTCCCTGGGCAAAG }\end{array}$ & NM_173984.2 & 137 \\
\hline PDK4 & $\begin{array}{l}\text { For: GGCCTAGTGTTGTGGTGCTTC } \\
\text { Rev: GAGCCAGAGTCCCATAATCAAG }\end{array}$ & NM_001101883.1 & 120 \\
\hline GAPDH & $\begin{array}{l}\text { For: GGCGTGAACCACGAGAAGTATAA } \\
\text { Rev: CССТCCACGATGCCAAAGT }\end{array}$ & BC102589 & 120 \\
\hline $18 S r R N A$ & $\begin{array}{l}\text { For: CGGCGACGACCCATTCGAAC } \\
\text { Rev: GAATCGAACCCTGATTCCCCGTC }\end{array}$ & AY779625 & 99 \\
\hline RPL19 & $\begin{array}{l}\text { For: TCGATGCCGGAAAAACAC } \\
\text { Rev: ATTCTCATCCTCCTCATCCAG }\end{array}$ & NM_001040516 & 119 \\
\hline
\end{tabular}

Gene products analysed are the insulin-like growth factors (IGF1/IGF2), IGF-binding proteins $1-6(I G F B P 1 / 2 / 3 / 4 / 5 / 6)$ and the acid labile subunit (IGFALS); the IGF receptors (IGF1R, IGF2R); insulin receptor (INSR); GH receptor (GHR); glucocorticoid receptor (NR3C1, Bos taurus nuclear receptor subfamily 3, group $C$, member 1, transcript variant 4); oestrogen receptors $A$ and $B(E S R 1, E S R 2)$; matrix metalloproteinases (MMP-1, -3 , -9 and -13); Alpha(2)-HS-glycoprotein (AHSG); pyruvate dehydrogenase kinase 4 (PD4K); glyceraldehyde-3-phosphate dehydrogenase (GAPDH); ribosomal protein L19 (RPL19). 
SYBR Green Mix (ABgene, Epsom, Surrey, UK), $500 \mathrm{nM}$ forward and reverse primers and nuclease-free water. Primer annealing and amplicon-specific melting temperatures were determined using the gradient function of the DNA Engine Opticon 2 thermal cycler (MJ Research, Inc., Waltham, MA, USA). Equivalent amounts of sample cDNA were added to each reaction in duplicate. To minimise variation, all samples included in each analysis were derived from the same RT batch, prepared under the same conditions and were analysed on a single plate. Thermal cycling conditions applied to each assay consisted of an initial Taq activation step at $95{ }^{\circ} \mathrm{C}$ for 15 min followed by 38 cycles of denaturation $\left(95^{\circ} \mathrm{C}\right)$, annealing (range $50.0-64.2^{\circ} \mathrm{C}$ ), extension $\left(72{ }^{\circ} \mathrm{C}\right.$ ) and an amplicon-specific fluorescence acquisition reading (range 74-84 ${ }^{\circ} \mathrm{C}$ ). A melting curve analysis was performed for each amplicon between 50 and $95^{\circ} \mathrm{C}$ and as such any smaller nonspecific products such as dimers were melted (if present) prior to fluorescence acquisition. All qPCR results were recorded with the Opticon Monitor Analysis Software (V2.02; MJ Research). For comparison of expression data, absolute values were derived from standard curves generated from purified cDNAs identical to amplified products and expressed as $\mathrm{fg} / \mu \mathrm{g}$ reverse-transcribed RNA.

\section{Statistical analysis}

Statistical analyses were performed using Statistical Package for the Social Sciences (SPSS for Windows, V13.0, Chicago, IL, USA). Differences in gene expression at the time of tissue collection between MNEB and SNEB groups were analysed using an independent samples $t$-test. Levene's test was used to account for variance and if homogeneity was not achieved an unequal variance $t$-test was used. The last blood sample measurement from each cow collected pre-slaughter was compared between the groups using t-test. For IGF1, GH, insulin and cortisol, a repeated measure ANOVA via a linear mixed effect model was also performed for samples collected during the 2 weeks after calving.

Relationships between absolute levels of expression for all genes measured by qPCR and between gene expression levels and blood hormone and metabolite measurements at slaughter were determined from values pooled across treatment groups. These calculations were also repeated using an analysis of covariance between the pairs of variables with the treatment included as a fixed effect.

Significance has been taken at $P<0.05$, although for the correlation data the rough false discovery rate was also used to adjust the level of significance (Benjamini \& Hochberg 1995). For the $t$-tests on the qPCR, data trends are also reported at $P<0.10$.

\section{Declaration of interest}

The authors declare that there is no conflict of interest that would prejudice the impartiality of this scientific work.

\section{Funding}

This project was supported by the Wellcome Trust (grant number 072315/Z/03/Z) and the Irish National Development Plan.

\section{Acknowledgements}

The authors would like to thank the valued contribution of the Teagasc Moorepark farm staff. Dr S Llewellyn performed the $\mathrm{GH}$ and cortisol RIAs and Ms R Stevens contributed to some of the PCR analyses. Manuscript ID P/VBS/000109.

\section{References}

Bach LA 1999 The insulin-like growth factor binding protein-6: the "forgotten" binding protein? Hormone and Metabolic Research 31 226-234. (doi:10.1055/s-2007-978723)

Bach LA 2005 IGFBP-6 five years on; not so 'forgotten'? Growth Hormone \& IGF Research 15 185-192. (doi:10.1016/j.ghir.2005.04.001)

Baumann DE \& Currie WB 1980 Partitioning of nutrients during pregnancy and lactation: a review of mechanisms involving homeostasis and homeorhesis. Journal of Dairy Science 63 1514-1529. (doi:10.3168/jds. S0022-0302(80)83111-0)

Bell AW 1995 Regulation of organic nutrient metabolism during transition from late pregnancy to early lactation. Journal of Animal Science $\mathbf{7 3}$ 2804-2819.

Benjamini Y \& Hochberg Y 1995 Controlling the false discovery rate: a practical and powerful approach to multiple testing. Journal of the Royal Statistical Society. Series B 57 289-300. (doi:10.2307/2346101)

Braundmeier AG \& Nowak RA 2006 Cytokines regulate matrix metalloproteinases in human uterine endometrial fibroblast cells through a mechanism that does not involve increases in extracellular matrix metalloproteinase inducer. American Journal of Reproductive Immunology 56 201-214. (doi:10.1111/j.1600-0897.2006.00418.x)

Clemmons DR 1997 Insulin-like growth factor binding proteins and their role in controlling IGF actions. Cytokine \& Growth Factor Reviews 8 45-62. (doi:10.1016/S1359-6101(96)00053-6)

Clemmons DR 2004 Role of insulin-like growth factor in maintaining normal glucose homeostasis. Hormone Research 62 (Supplement) 177-182. (doi:10.1159/000080763)

Coppock HA, White A, Aplin JD \& Westwood M 2004 Matrix metalloprotease-3 and -9 proteolyze insulin-like growth factor-binding protein-1. Biology of Reproduction 71 438-443. (doi:10.1095/biolreprod.103.023101)

Dahlgren LA, Mohammed HO \& Nixon AJ 2005 Temporal expression of growth factors and matrix molecules in healing tendon lesions. Journal of Orthopaedic Research 23 84-92. (doi:10.1016/j.orthres.2004.05.007)

Del Prato S, Vigili de Kreutzenberg S, Riccio A \& Tiengo A 1991 Hepatic sensitivity to insulin: effects of sulfonylurea drugs. American Journal of Medicine 90 29S-36S. (doi:10.1016/0002-9343(91)90415-T)

Drackley JK, Overton TR \& Douglas GN 2001 Adaptations of glucose and long-chain fatty acid metabolism in liver of dairy cows during the periparturient period. Journal of Dairy Science 84 E100-E112. (doi:10. 3168/jds.S0022-0302(01)70204-4)

Fenwick MA, Fitzpatrick R, Kenny DA, Diskin MG, Patton J, Murphy JJ \& Wathes DC 2008a Interrelationships between negative EB (NEB) and IGF regulation in liver of lactating dairy cows. Domestic Animal Endocrinology 34 31-44. (doi:10.1016/j.domaniend.2006.10.002)

Fenwick MA, Llewellyn S, Fitzpatrick R, Kenny DA, Murphy JJ, Patton J \& Wathes DC 2008b Negative energy balance in dairy cows is associated with specific changes in IGF-binding protein expression in the oviduct. Reproduction 135 63-75. (doi:10.1530/REP-07-0243)

Foldi J, Kulcsar M, Pecsi A, Huyghe B, de Sa C, Lohuis JA, Cox P \& Huszenicza G 2006 Bacterial complications of postpartum uterine involution in cattle. Animal Reproduction Science 96 265-281. (doi:10. 1016/j.anireprosci.2006.08.006)

Fourichon C, Seegers H \& Malher X 1999 Effects of disease on reproduction in the dairy cow. A meta-analysis. Theriogenology 53 1729-1759. (doi:10.1016/S0093-691X(00)00311-3)

Gable KL, Maddux BA, Penaranda C, Zavodovskaya M, Campbell MJ, Lobo M, Robinson L, Schow S, Kerner JA, Goldfine ID et al. 2006 Diarylureas are small-molecule inhibitors of insulin-like growth factor I receptor signaling and breast cancer cell growth. Molecular Cancer Therapeutics 5 1079-1086. (doi:10.1158/1535-7163.MCT-05-0397) 
Ganeff C, Chatel G, Munaut C, Frankenne F, Foidart JM \& Winkler R 2009 The IGF system in in-vitro human decidualization. Molecular Human Reproduction 15 27-38. (doi:10.1093/molehr/gan073)

Geisert RD, Lee CY, Simmen FA, Zavy MT, Fliss AE, Bazer FW \& Simmen RCM 1991 Expression of messenger RNAs encoding insulin-like growth factor-I, -II, and insulin-like growth factor binding protein-2 in bovine endometrium during the estrous cycle and early pregnancy. Biology of Reproduction 45 975-983. (doi:10.1095/biolreprod45.6.975)

Gier HT \& Marion GB 1968 Uterus of the cow after parturition: involutional changes. American Journal of Veterinary Research 29 83-96.

Gilbert RO, Shin ST, Guard CL, Erb HN \& Frajblat M 2005 Prevalence of endometritis and its effects on reproductive performance of dairy cows. Theriogenology 64 1879-1888. (doi:10.1016/j.theriogenology.2005. 04.022)

Giudice LC 2006 Endometrium in PCOS: implantation and predisposition to endocrine CA. Best Practice \& Research. Clinical Endocrinology \& Metabolism 20 235-244. (doi:10.1016/j.beem.2006.03.005)

Grazul-Bilska AT, Johnson ML, Bilski JJ, Redmer DA, Reynolds LP, Abdullah A \& Abdullah KM 2003 Wound healing: the role of growth factors. Drugs of Today 39 787-800. (doi:10.1358/dot.2003.39.10. 799472)

Grellier P, Berrebi D, Peuchmaur M \& Babajko S 2002 The IGF system in neuroblastoma xenografts: focus on IGF-binding protein-6. Journal of Endocrinology 172 467-476. (doi:10.1677/joe.0.1720467)

Grummer RR 1995 Impact of changes in organic nutrient metabolism on feeding the transition dairy cow. Journal of Animal Science $\mathbf{7 3}$ 2820-2833.

Holness MJ \& Sugden MC 2003 Regulation of pyruvate dehydrogenase complex activity by reversible phosphorylation. Biochemical Society Transactions 31 1143-1151. (doi:10.1042/BST0311143)

Jarrige J 1989 INRAtion V2.7: Microsoft computer program of ration formulation for ruminant livestock. In Logiciel de Rationnement des Ruminants. Eds J Agabriel, P Champciaux \& C Espinasse. Dijon, France: CNERTA.

Kalabay L, Cseh K, Pajor A, Baranyi E, Csakany GM, Melczer Z, Speer G, Kovacs M, Siller G, Karadi I et al. 2002 Correlation of maternal serum fetuin/alpha2-HS-glycoprotein concentration with maternal insulin resistance and anthropometric parameters of neonates in normal pregnancy and gestational diabetes. European Journal of Endocrinology 147 243-248. (doi:10.1530/eje.0.1470243)

Kirwan JP, Varastehpour A, Jing M, Presley L, Shao J, Friedman JE \& Catalano PM 2004 Reversal of insulin resistance postpartum is linked to enhanced skeletal muscle insulin signaling. Journal of Clinical Endocrinology and Metabolism 89 4678-4684. (doi:10.1210/jc.20040749)

Kobayashi Y, Boyd CK, Bracken CJ, Lamberson WR, Keisler DH \& Lucy MC 1999 Reduced growth hormone receptor (GHR) messenger ribonucleic acid in liver of periparturient cattle is caused by a specific down-regulation of GHR 1A that is associated with decreased insulin-like growth factor I. Endocrinology 140 3947-3954. (doi:10.1210/en.140.9.3947)

Koehler KF, Helguero LA, Haldosén LA, Warner M \& Gustafsson JA 2005 Reflections on the discovery and significance of estrogen receptor beta. Endocrine Reviews 26 465-478. (doi:10.1210/er.2004-0027)

Kölle S, Sinowatz F, Boie G, Lincoln D \& Waters MJ 1997 Differential expression of the growth hormone receptor and its transcript in bovine uterus and placenta. Molecular and Cellular Endocrinology 131 127-136. (doi:10.1016/S0303-7207(97)00097-X)

Kornfeld S 1992 Structure and function of the mannose 6-phosphate/insulin-like growth factor II receptors. Annual Reviews of Biochemistry 61 307-330. (doi:10.1146/annurev.bi.61.070192.001515)

Kübler D, Gosenca D, Wind M, Heid H, Friedberg I, Jahnen-Dechent W \& Lehmann WD 2007 Proteolytic processing by matrix metalloproteinases and phosphorylation by protein kinase CK2 of fetuin-A, the major globulin of fetal calf serum. Biochimie 89 410-418. (doi:10.1016/ j.biochi.2006.10.012)

Laven RA, Scaramuzzi RJ, Wathes DC, Peters AR \& Parkinson TJ 2007 Recent research on the effects of excess dietary nitrogen on the fertility of dairy cows. Veterinary Record 160 359-362. (doi:10.1136/vr.160. 11.359)

Lee CY, Kwak I, Chung CS, Choi WS, Simmen RC \& Simmen FA 2001 Molecular cloning of the porcine acid-labile subunit (ALS) of the insulin-like growth factor-binding protein complex and detection of ALS gene expression in hepatic and non-hepatic tissues. Journal of Molecular Endocrinology 26 135-144. (doi:10.1677/jme.0.0260135)

Leite-Browning ML, McCawley LJ, Choi OH, Matrisian LM \& Ochieng J 2002 Interactions of alpha2-HS-glycoprotein (fetuin) with MMP-3 and murine squamous cell carcinoma cells. International Journal of Oncology 21 965-971.

Leroy JL, Vanholder T, Van Knegsel AT, Garcia-Ispierto I \& Bols PE 2008 Nutrient prioritization in dairy cows early postpartum: mismatch between metabolism and fertility? Reproduction in Domestic Animals 43 (Supplement 2) 96-103. (doi:10.1111/j.1439-0531.2008.01148.x)

Leslie KE 1983 The events of normal and abnormal postpartum endocrinology and uterine involution in dairy cows: a review. Canadian Veterinary Journal 24 67-71.

Leung KC, Johannsson G, Leong GM \& Ho KK 2004 Estrogen regulation of growth hormone action. Endocrine Reviews 25 693-721. (doi:10.1210/ er.2003-0035)

Lewis GS 1997 Symposium: health problems of the postpartum cow. Journal of Dairy Science 80 984-994. (doi:10.3168/jds.S0022-0302(97)76024-7)

Li S, Ren J \& Huang L 2007 Characterization of the porcine insulin-like growth factor-binding protein, acid-labile subunit gene: full-length cDNA and DNA sequence, polymorphisms and expression profile. Journal of Animal Breeding and Genetics 124 133-138. (doi:10.1111/ j.1439-0388.2007.00645.x)

Llewellyn S 2008 Influence of energy balance on the insulin-like growth factor system in the reproductive tract of post partum dairy cows. $P h D$ Thesis. University of London.

Llewellyn S, Fitzpatrick R, Kenny DA, Murphy JJ, Scaramuzzi RJ \& Wathes DC 2007 Effect of negative energy balance on the insulin-like growth factor system in pre-recruitment ovarian follicles of post partum dairy cows. Reproduction 133 627-639. (doi:10.1530/REP-06-0122)

Llewellyn S, Fitzpatrick R, Kenny DA, Patton J \& Wathes DC 2008 Endometrial expression of the insulin-like growth factor system during uterine involution in the postpartum dairy cow. Domestic Animal Endocrinology 34 391-402. (doi:10.1016/j.domaniend.2007.11.003)

Lucy MC, Jiang H \& Kobayashi Y 2001 Changes in the somatotrophic axis associated with the initiation of lactation. Journal of Dairy Science $\mathbf{8 4}$ E113-E119. (doi:10.3168/jds.S0022-0302(01)70205-6)

Manase K, Endo T, Chida M, Nagasawa K, Honnma H, Yamazaki K, Kitajima Y, Goto T, Kanaya M, Hayashi T et al. 2006 Coordinated elevation of membrane type 1-matrix metalloproteinase and matrix metalloproteinase-2 expression in rat uterus during postpartum involution. Reproductive Biology and Endocrinology 4 32. (doi:10.1186/14777827-4-32)

Marion GB \& Gier HT 1959 Histological and cytological changes in the bovine uterine epithelium. Journal of Animal Science 18 1552-1553.

Mateus L, Lopes da Costa L, Bernardo F \& Robalo Silva J 2002 Influence of puerperal uterine infection on uterine involution and postpartum ovarian activity in dairy cows. Reproduction in Domestic Animals 37 31-35. (doi:10.1046/j.1439-0531.2002.00317.x)

Meyer HH, Mittermeier T \& Schams D 1988 Dynamics of oxytocin, estrogen and progestin receptors in the bovine endometrium during the estrous cycle. Acta Endocrinologica 118 96-104. (doi:10.1530/acta.0. 1180096)

Mourkioti F \& Rosenthal N 2005 IGF-1, inflammation and stem cells: interactions during muscle regeneration. Trends in Immunology 26 535-542. (doi:10.1016/j.it.2005.08.002)

Murphy LJ \& Friesen HG 1988 Differential effects of estrogen and growth hormone on uterine and hepatic insulin-like growth factor I gene expression in the ovariectomized hypophysectomized rat. Endocrinology 122 325-332. (doi:10.1210/endo-122-1-325)

Nagase H, Visse R \& Murphy G 2006 Structure and function of matrix metalloproteinases and TIMPs. Cardiovascular Research 69 562-573. (doi:10.1016/j.cardiores.2005.12.002)

Ning Y, Schuller AG, Conover CA \& Pintar JE 2008 Insulin-like growth factor (IGF) binding protein-4 is both a positive and negative regulator of IGF activity in vivo. Molecular Endocrinology 22 1213-1225. (doi:10. 1210/me.2007-0536)

Ochieng J, Warfield P \& Green B 1995 Interactions of gelatinases with soluble and immobilized fetuin and asialofetuin. Archives of Biochemistry and Biophysics 322 250-255. (doi:10.1006/abbi.1995.1459) 
Osgerby JC, Gadd TS \& Wathes DC 1999 Expression of insulin-like growth factor binding protein-1 (IGFBP-1) mRNA in the ovine uterus throughout the oestrous cycle and early pregnancy. Journal of Endocrinology $\mathbf{1 6 2}$ 279-287. (doi:10.1677/joe.0.1620279)

Patton J, Kenny DA, Mee JF, O'Mara FP, Wathes DC, Cook M \& Murphy JJ 2006 Effect of milking frequency and diet on milk production, energy balance, and reproduction in dairy cows. Journal of Dairy Science $\mathbf{8 9}$ 1478-1487. (doi:10.3168/jds.S0022-0302(06)72215-9)

Pershing RA, Lucy MC, Thatcher WW \& Badinga L 2002 Effects of BST on oviductal and uterine genes encoding components of the IGF system in lactating dairy cows. Journal of Dairy Science 85 3260-3267. (doi:10. 3168/jds.S0022-0302(02)74414-7)

Prisk V \& Huard J 2003 Muscle injuries and repair: the role of prostaglandins and inflammation. Histology and Histopathology 18 $1243-1256$.

Rasche A, Al-Hasani H \& Herwig R 2008 Meta-analysis approach identifies candidate genes and associated molecular networks for type-2 diabetes mellitus. BMC Genomics 9 310. (doi:10.1186/1471-2164-9-310)

Ray S, Lukyanov P \& Ochieng J 2003 Members of the cystatin superfamily interact with MMP-9 and protect it from autolytic degradation without affecting its gelatinolytic activities. Biochimica et Biophysica Acta 1652 91-102.

Rhoads ML, Gilbert RO, Lucy MC \& Butler WR 2004 Effects of urea infusion on the uterine luminal environment of dairy cows. Journal of Dairy Science 87 2896-2901. (doi:10.3168/jds.S0022-0302(04)73420-7)

Rhoads ML, Meyer JP, Lamberson WR, Keisler DH \& Lucy MC 2008 Uterine and hepatic gene expression in relation to days postpartum, estrus, and pregnancy in postpartum dairy cows. Journal of Dairy Science 91 140-150. (doi:10.3168/jds.2007-0439)

Robinson RS, Mann GE, Gadd TS, Lamming GE \& Wathes DC 2000 The expression of the IGF system in the bovine uterus throughout the oestrous cycle and early pregnancy. Journal of Endocrinology 165 231-243. (doi:10.1677/joe.0.1650231)

Robinson RS, Mann GE, Lamming GE \& Wathes DC 2001 Expression of oxytocin, oestrogen and progesterone receptors in uterine biopsy samples throughout the oestrous cycle and early pregnancy in cows. Reproduction 122 965-979. (doi:10.1530/rep.0.1220965)

Rutanen EM 1998 Insulin-like growth factors in endometrial function. Gynecological Endocrinology 12 399-406. (doi:10.3109/09513599 809012842)

Rutkute K \& Nikolova-Karakashian MN 2007 Regulation of insulin-like growth factor binding protein-1 expression during aging. Biochemical and Biophysical Research Communications 361 263-269. (doi:10.1016/ j.bbrc.2007.06.079)

Salamonsen LA 2003 Tissue injury and repair in the female human reproductive tract. Reproduction 125 301-311. (doi:10.1530/rep.0. 1250301)

Salamonsen LA, Zhang J \& Brasted M 2002 Leukocyte networks and human endometrial remodelling. Journal of Reproductive Immunology $\mathbf{5 7}$ 95-108. (doi:10.1016/S0165-0378(02)00011-6)

Schäubli M, Ritter N, Hässig M, Zerbe H, Bleul U \& Boos A 2008 Progesterone receptors, oestrogen receptor alpha and glucocorticoid receptors in the bovine intercaruncular uterine wall around parturition. Animal Reproduction Science 103 215-227. (doi:10.1016/j.anireprosci. 2006.12.015)

Sheldon IM, Cronin J, Goetze L, Donofrio G \& Schuberth HJ 2009 Defining postpartum uterine disease and the mechanisms of infection and immunity in the female reproductive tract in cattle. Biology of Reproduction 81 1025-1032. (doi:10.1095/biolreprod.109.077370)

Shepherd PR 2005 Mechanisms regulating phosphoinositide 3-kinase signaling in insulin-sensitive tissues. Acta Physiologica Scandinavica 183 3-12. (doi:10.1111/j.1365-201X.2004.01382.x)

Sivan E \& Boden G 2003 Free fatty acids, insulin resistance, and pregnancy. Current Diabetes Reports 3 319-322. (doi:10.1007/s11892-003-0024-y)

Sivan E, Chen X, Homko CJ, Reece EA \& Boden G 1997 Longitudinal study of carbohydrate metabolism in healthy obese pregnant women. Diabetes Care 20 1470-1475. (doi:10.2337/diacare.20.9.1470)

Stefan N, Hennige AM, Staiger H, Machann J, Schick F, Krober SM, Machicao F, Fritsche A \& Haring HU 2006 Alpha2-Heremans-Schmid
glycoprotein/fetuin-A is associated with insulin resistance and fat accumulation in the liver in humans. Diabetes Care 29 853-857. (doi:10.2337/diacare.29.04.06.dc05-1938)

Stevenson KR, Gilmour RS \& Wathes DC 1994 Localization of insulin-like growth factor-I (IGF-I) and -II messenger ribonucleic acid and type 1 IGF receptors in the ovine uterus during the estrous cycle and early pregnancy. Endocrinology 134 1655-1664. (doi:10.1210/en.134. 4.1655)

Taylor VJ, Cheng Z, Pushpakumara PG, Beever DE \& Wathes DC 2004 Relationships between the plasma concentrations of insulin-like growth factor-I in dairy cows and their fertility and milk yield. Veterinary Record 155 583-588. (doi:10.1136/vr.155.19.583)

Thatcher WW, Bilby TR, Bartolome JA, Silvestre F, Staples CR \& Santos JEP 2006 Strategies for improving fertility in the modern dairy cow. Theriogenology 65 30-44. (doi:10.1016/j.theriogenology.2005.10.004)

Thissen JP, Ketelslegers JM \& Underwood LE 1994 Nutritional regulation of the insulin-like growth factors. Endocrine Reviews 15 80-101. (doi:10. 1210/edrv-15-1-80)

Toyofuku A, Hara T, Taguchi T, Katsura Y, Ohama K \& Kudo Y 2006 Cyclic and characteristic expression of phosphorylated Akt in human endometrium and decidual cells in vivo and in vitro. Human Reproduction $\mathbf{2 1}$ 1122-1128. (doi:10.1093/humrep/dei454)

Wathes DC, Reynolds TS, Robinson RS \& Stevenson KR 1998 Role of the insulin-like growth factor system in uterine function and placental development in ruminants. Journal of Dairy Science 81 1778-1789. (doi:10.3168/jds.S0022-0302(98)75747-9)

Wathes DC, Fenwick M, Cheng Z, Bourne N, Llewellyn S, Morris DG, Kenny D, Murphy J \& Fitzpatrick R 2007 a Influence of negative energy balance on cyclicity and fertility in the high producing dairy cow. Theriogenology 68 (Supplement 1) S232-S241. (doi:10.1016/j.theriogenology.2007.04.006)

Wathes DC, Bourne N, Cheng Z, Mann GE, Taylor VJ \& Coffey MP $2007 b$ Multiple correlation analyses of metabolic and endocrine profiles with fertility in primiparous and multiparous cows. Journal of Dairy Science 90 1310-1325. (doi:10.3168/jds.S0022-0302(07)71619-3)

Wathes DC, Cheng Z, Bourne N, Taylor VJ, Coffey MP \& Brotherstone S $2007 c$ Differences between primiparous and multiparous dairy cows in the inter-relationships between metabolic traits, milk yield and body condition score in the periparturient period. Domestic Animal Endocrinology 33 203-225. (doi:10.1016/j.domaniend.2006.05.004)

Wathes DC, Cheng Z, Chowdhury W, Fenwick MA, Fitzpatrick R, Morris DG, Patton J \& Murphy JJ 2009 Negative energy balance alters global gene expression and immune responses in the uterus of postpartum dairy cows. Physiological Genomics 39 1-13. (doi:10. 1152/physiolgenomics.00064.2009)

Werner H \& Roberts CT 2003 The IGFI receptor gene: a molecular target for disrupted transcription factors. Genes Chromosomes \& Cancer 36 113-120. (doi:10.1002/gcc.10157)

Wetterau LA, Moore MG, Lee KW, Shim ML \& Cohen P 1999 Novel aspects of the insulin-like growth factor binding proteins. Molecular Genetics and Metabolism 68 161-181. (doi:10.1006/mgme.1999.2920)

White MF 2006 Regulating insulin signaling and beta-cell function through IRS proteins. Canadian Journal of Physiology and Pharmacology $\mathbf{8 4}$ 725-737. (doi:10.1139/Y06-008)

Zerbe H, Schneider N, Leibold W, Wensing T, Kruip TA \& Schuberth HJ 2000 Altered functional and immunophenotypical properties of neutrophilic granulocytes in postpartum cows associated with fatty liver. Theriogenology 54 771-786. (doi:10.1016/S0093-691X(00)003897)

Zhu X, Ling N \& Shimasaki S 1993 Structural characterization of the rat insulin-like growth factor binding protein-6 gene. Biochemical and Biophysical Research Communications 191 1237-1243. (doi:10.1006/ bbrc.1993.1350)

Received 7 April 2010

First decision 10 May 2010

Revised manuscript received 1 November 2010

Accepted 26 November 2010 